\title{
KEKUATAN ALAT BUKTI KETERANGAN SAKSI YANG MEMILIKI HUBUNGAN DARAH DENGAN TERDAKWA DALAM TINDAK PIDANA PENCURIAN DALAM KELUARGA
}

\author{
I Gede Agus Sudiantara, Anak Agung Sagung Laksmi Dewi, Ni Made Sukaryati Karma \\ Fakultas Hukum, Universitas Warmadewa, Denpasar-Bali, Indonesia \\ gedeagussudiantara@gmail.com, laksmiidewi29@gmail.com madesukaryatikarma@gmail.com
}

\begin{abstract}
Abstrak
Kekuatan dari alat bukti dari saksi yang memiliki keterkaitan keluarga dengan terdakwa dalam tindak pidana pencurian dalam keluarga, proses pemeriksaan terhadap saksi merupakan alat bukti yang utama dalam suatu tindak pidana. Adapun tujuan penelitian ini yaitu untuk mengungkap kekuatan alat bukti keterangan saksi yang memiliki hubungan darah dengan terdakwa dalam proses pembuktian dan hambatan pembuktian dengan menggunakan alat bukti keterangan saksi yang memiliki hubungan darah dengan terdakwa dalam tindak pidana pencurian dalam keluarga. Metode penelitian yang digunakan adalah penelitian hukum normatif. Sumber bahan hukum primer dan sekunder. Bahan-bahan hukum yang telah didapat dari studi kepustakaan dan pendekatan perundang-undangan dianalisis dengan teknik interpretasi sistematis. Hasil penelitian mengungkapkan bahwa Keterangan saksi sangat diperlukan dalam persidangan guna untuk memberikan sanksi yang tepat bagi terdakwa. Hambatan pembuktian dari keterangan saksi yang memiliki hubungan dan ikatan dalam keluarga adalah apabila asas minimum pembuktian tidak dapat dibuktikan. Dapat disimpulkan kekuatan dari keterangan saksi yang tidak mengucap sumpah, maka tidak dapat dianggap sebagai alat bukti, melainkan hanya keterangan yang dipertimbangkan hakim.
\end{abstract}

Kata Kunci: Keterangan Saksi, Pencurian, Tindak Pidana

\begin{abstract}
The strength of evidence from witnesses who have family ties to the defendant in the crime of theft in the family, the process of examining witnesses is the main evidence in a crime. The purpose of this study is to reveal the strength of the evidence of witnesses who have blood relations with the defendant in the evidentiary process and barriers to proof by using evidence of witnesses who have blood relations with the defendant in the crime of theft in the family. The research method used is normative legal research. Sources of primary and secondary legal materials. Legal materials that have been obtained from the literature study and the approach to legislation were analyzed using a systematic interpretation technique. The results of the study reveal that witness testimony is very necessary in the trial in order to provide appropriate sanctions for the defendant. The barrier to proof from witness statements who have family relationships and ties is if the minimum principle of proof cannot be proven. It can be concluded that the strength of the testimony of a witness who does not take an oath, cannot be considered as evidence, but only information that is considered by the judge.
\end{abstract}

Keywords: Witness Statement, Theft, Crime

\section{PENDAHULUAN}

Hukum merupakan aturan yang dibuat dengan tujuan untuk membatasi individu dalam bertingkah laku di kehidupan bermasyarakat dan bernegara, guna memberikan dan menciptakan kenyamanan, suasana yang tertib dan aman bagi masyarakat (Marzuki, 2008). Indonesia memiliki pengaturan hukum yang didalamnya secara khusus mengatur tentang hukum pidana. Hukum pidana diharapkan dapat memberikan rasa aman dan tertib, serta diharapkan juga dapat melindungi hak asasi manusia dan menjadi sarana penegakan keadilan bagi mereka yang menjadi korban tindak pidana (Husin, 2016).

Indonesia merupakan negara hukum yang dapat dilihat dari ciri-ciri sebagai berikut: pengakuan dan perlindungan terhadap hak asasi manusia memiliki kesamaan hak di bidang politik, 
hukum, sosial, kebudayaan dan memiliki sistem peradilan yang bebas dan tidak memihak dalam mengadili perkara serta tidak dapat dipengaruhi oleh siapapun baik dalam peradilannya dan menjatuhkan putusannya.

Dalam melaksanakan dan menerapkan sistem peradilan yang bebas negara mewujudkannya dengan menciptakan pengaturan mengenai sistem peradilan seperti yang tertuang dalam Kitab Undang-Undang Hukum Acara Pidana. Dalam hukum acara pidana terdapat kekuatan alat bukti, yang dimana alat bukti menjadi acuan dalam penjatuhan putusan dari pengadilan terhadap terdakwa yang telah dinyatakan bersalah.

Dalam penyelesaiin perkara pidana seseorang dapat dijatuhkan pidana apabila sudah terbukti bersalah dalam proses persidangan dan dibuktikan dengan adanya putusan yang memiliki kekuatan hukum. Penjatuhan putusan diperkuat dengan adanya alat bukti yang berupa: keterangan saksi, surat petunjuk, keterangan dari ahli dan keterangan terdakwa (Harahap, 2012).

Keterangan saksi merupakan alat bukti yang yang menjadi acuan dalam penjatuhan putusan, mengingat terjadinya suatu perkara pidana tidak luput dari keterangan saksi. Pembuktian dari suatu perkara pidana selalu menitikberatkan pada keterangan saksi. Keterangan saksi dapat dikatakan sah apabila sudah mengucapkan sumpah, keterangan dari saksi harus diberikan di pengadilan dan keterangan saksi yang diperkuat oleh saksi lainnya.

Tindak pidana atau kasus pidana yang kerap kali terjadi di masyarakat adalah pencurian. Ada beberapa kasus pencurian yang terjadi dan pencuriaan tersebut dilakukan oleh mereka yang memiliki hubungan darah atau keluarga antara pelaku dan korbannya, hubungan darah tersebut dapat dilihat dari hubungannya yang meliputi, ayah dan anaknya, ibu dengan anaknya atau sesama saudara baik itu kandung atau saudara tiri. Hukum acara pidana memiliki tujuan mencari dan mendapatkan kebenaran yang selengkap-lengkapnyan dan dapat dipertanggungjawabkan dimuka pengadilan guna mencari terdakwa atas suatu perkara pidana atau pelanggaran hukum. Pembuktian dapat dilakukan dengan menyelidiki alat-alat bukti yang telah dikumpulkan dan ditentukan oleh undang-undang. Dengan begitu dapat mempermudah hakim dalam menjatuhkan putusan terhadap suatu perkara pidana. (Remincel, 2019) dalam Hukum Acara Pidana yang diatur dalam Kitab-Undang-Undang Hukum acara Pidana (KUHAP) mengatur tentang alat bukti yang diperlukan dalam penyelesaian suatu perkara pidana terutama dalam masalah pembuktian.

Persidangan merupakan proses yang sangat penting dalam penjatuhan sanksi pidana yang akan diberikan untuk terdakwa. Dikatakan penting karena dalam persidangan terdakwa dapat ditetapkan bersalah atau tidak, dan pembuktiannya diperlukan atau dilakukan dengan menyertakan alat-alat bukti seperti yang sudah ditetapkan oleh undang-undang. Keluarga merupakan kelompok terkecil dalam masyarakat, dan pada akhirnya keluarga dapat membentuk masyarakat. Di Dalam keluarga itu sendiri sering terjadinya tindak pidana yang diantaranya meliputi, pembunuhan, pencurian, pelecehan, penipuan dan pemerkosaan. Dan kejahatan yang memiliki intensitas dan peluang paling besar terjadi di keluarga adalah pencurian, yang pelakunya masih memiliki ikatan atau hubungan darah dengan korban dan juga saksi yang masih memiliki ikatan atau hubungan darah dengan pelaku dan korban itu sendiri.

Pencurian yang terjadi dalam suatu keluarga, dalam proses penyelidikan dan penyidikan akan dicari informasi tentang siapa pemilik rumah tersebut, dan memiliki kedekatan dengan korban, yang sering melakukan kunjungan ke rumah tersebut dan beberapa bukti yang didapatkan di tempat kejadian yang memiliki keterkaitan dengan pencurian. Jadi, kemungkinan ditemukannya saksi atas kejadian tersebut dan memiliki hubungan darah baik dengan korban serta terdakwa. Secara normatif meskipun ada hubungan dara antara saksi dan terdakwa, keterangan dapat diberikan dan tergantung dengan jaksa dan terdakwa itu sendiri menyetujui atau tidak.

Berdasarkan penelitian sebelumnya, menurut (Kamu, 2019) Salah satu pasal dalam KUHAP yang berkaitan dengan pembuktian adalah Pasal 183 KUHAP yang berbunyi hakim tidak boleh menjatuhkan pidana kepada seorang kecuali apabila dengan sekurangkurangnya dua alat bukti yang sah ia memperoleh keyakinan bahwa suatu tindak pidana benar-benar terjadi dan bahwa terdakwalah yang bersalah melakukannya. Pemberian kesaksian oleh seorang yang mempunyai hubungan keluarga sedarah dengan terdakwa dalam persidangan diberikan di bawah sumpah yang dilakukan atas kehendak mereka dan kehendaknya itu disetujui secara tegas oleh penuntut umum dan terdakwa, memiliki nilai sebagai alat bukti yang sah, mempunyai kekuatan pembuktian yang bersifat bebas dan "tidak sempurna" dan tidak "menentukan" atau "tidak mengikat". Nilai kekuatan pembuktiannya 
tergantung pada penilaian hakim (Pratiwi \& P., 2016). Alat bukti yang sah dalam Pasal 184 KUHAP ialah: keterangan saksi, keterangan ahli, surat, petunjuk, dan keterangan terdakwa (W, 2017). Lebih lanjut, hakim dalam menilai keterangan saksi di bawah sumpah harus dikaitkan dengan keterangan saksi lain yang disumpah dan alat bukti lain. Keterkaitan itu akan dihasilkan fakta-fakta yang saling berkaitan sebagai petunjuk bagi hakim untuk memutus perkara dan keterangan saksi yang masih berhubungan dengan keluarga sesuai Pasal 168 KUHAP (Nofandhi, 2018).

Maka berdasarkan penjelasan diatas, penelitian ini bertujuan untuk mengungkap kekuatan alat bukti keterangan saksi yang memiliki hubungan darah dengan terdakwa dalam proses pembuktian dan hambatan pembuktian dengan menggunakan alat bukti keterangan saksi yang memiliki hubungan darah dengan terdakwa dalam tindak pidana pencurian dalam keluarga.

\section{METODE PENELITIAN}

Penelitian ini termasuk kedalam penelitian hukum normatif, yang dikaji menggunakan studi kepustakaan yang berupa bahan-bahan hukum. Penelitian ini memiliki lingkup yang luas dan pendekatan masalah yang digunakan adalah pendekatan perundang-undangan dan pendekatan konseptual. Teknik pengumpulan bahan hukum yang digunakan adalah: bahan hukum primer yang didapat dengan menganalisis peraturan perundang-undangan, risalah resmi, dan beberapa keputusankeputusan yang menyangkut dengan judul tulisan ini. bahan hukum sekunder didapat dari menganalisis buku-buku, jurnal-jurnal dan hasil-hasil penelitian terdahulu yang memiliki keterkaitan dengan judul penulisan ini. Bahan-bahan hukum yang telah didapat dari studi kepustakaan dan pendekatan perundang-undangan dianalisis dengan teknik interpretasi sistematis yang dimana dalam analisis ini melibatkan suatu aturan yang memiliki keterkaitan dengan peraturan lainnya dan tidak ada peraturan yang dapat berdiri sendiri tanpa memiliki hubungan dengan peraturan lainnya sehingga memperoleh gambaran baru mengenai masalah hukum tersebut, sehingga mendapat kesimpulan dan penjelasan mengenai permasalahan baik itu dalam bentuk kebenaran ataupun sebaliknya dan semua akan dituangkan dalam penelitian ini.

\section{HASIL DAN PEMBAHASAN}

\section{Kekuatan Alat Bukti Keterangan Saksi yang Memiliki Hubungan Darah dengan Terdakwa Dalam Proses Pembuktian}

Tindak pidana merupakan suatu perbuatan yang melanggar ketentuan hukum yang berlaku, baik dilakukan dengan sengaja atau tidak sengaja dan harus dipertanggungjawabkan di persidangan sesuai dengan ketentuan peraturan perundang-undangan yang berlaku. Dalam proses penyidikan tindak pidana adanya pembuktian, yang dimana dalam penyelidikan perlu diperkuat dengan adanya barang bukti.

Dalam hukum acara pidana barang bukti merupakan suatu hal yang sangat penting guna mempermudah menguak suatu tindak pidana seperti yang dijelaskan didalam undang-undang (Waluyo, 1991). Alat bukti yang dapat dikatakan sah menurut undang=undang adalah, keterangan dari saksi, keterangan dari ahli, surat, petunjuk dan keterangan dari terdakwa itu sendiri.

Keterangan dari saksi itu sendiri merupakan salah satu alat bukti kuat yang dapat menguak suatu tindak pidana, karena saksi melihat, mendengar dan berada di dekat lokasi terjadinya suatu tindak pidana. Sehingga keterangan dari saksi dapat mempermudah proses penyelidikan, penyidikan penuntutan dan penjatuhan putusan dalam peradilan. Keterangan ahli merupakan keterangan atau pendapat yang diberikan secara langsung oleh orang yang dianggap memiliki pengetahuan atau kompetensi terhadap suatu tindak pidana, sehingga diharapkan dapat membantu memberikan referensi dan gambaran bagi hakim dalam menjatuhkan putusan dalam persidangan.

Surat merupakan pencurahan isi hati yang dapat dituangkan dalam bentuk tulisan guna menyampaikan buah pikiran dari seseorang yang dapat digunakan sebagai alat pembuktian. Suratsurat yang dapat digunakan adalah, surat yang dirancang oleh mereka yang berwenang yang didalamnya berisi mengenai kejadian yang dilihat, surat keterangan dari seorang ahli dan surat yang memiliki keterkaitan dengan tindak pidana yang dimaksud.

Petunjuk merupakan suatu bukti yang berupa perbuatan atau informasi yang didapat atau telah dianalisis dengan barang bukti lainnya sehingga memberikan suatu gambaran yang dapat menjadi titik terang baik dalam proses penyelidikan, penyidikan dan persidangan. Keterangan terdakwa merupakan suatu pernyataan yang disampaikan oleh terdakwa itu sendiri, sesuai dengan 
napa yang telah dilakukan baik itu berupa pengakuan ataupun pengelakan dan akan dijadikan sebagai alat bukti dan pertimbangan dalam penyelesaiaan suatu tindak pidana.

Keterangan saksi merupakan informasi yang diperoleh dari seseorang atau lebih yang ada atau mengetahui suatu peristiwa tindak pidana. Keterangan saksi dapat dinyatakan sah apabila disampaikan di persidangan. Keterangan saksi belum cukup dinyatakan sebagai alat bukti yang kuat, melainkan keterangan saksi harus ditunjang dengan alat bukti lainnya dan dapat memperkuat dan mempertegas keterangan dari saksi akan suatu tindak pidana.

Saksi dalam tindak pidana dapat dibedakan menjadi dua, yaitu saksi yang meringankan dan saksi yang memberatkan (Alfitra, 2018). Saksi yang meringankan adalah saksi yang diajukan oleh tersangka guna memberikan keterangan yang dapat meringankan hukuman bagi tersangka, dan saksi yang memberatkan adalah saksi yang memberikan keterangan dengan menguatkan tuntutan dari jaksa sehingga memberatkan terdakwa.

Saksi yang memberikan keteranga harus disumpah sebelumnya, apabila saksi tidak berkenan untuk disumpah maka keterangannya dapat dinyatakan tidak sah melainkan hanya menjadi keterangan, tetapi apabila keteragan dari saksi yang tidak sah memiliki kesanaaman dengan saksi yang sah maka keterangan saksi itu dapat dipergunakan. Sehingga keterangan yang diberikan oleh saksi yang tidak bersumpah maka akan dijadikan sebagai petuntuk bagi hakim saja.

\section{Hambatan Pembuktian dengan Menggunakan Alat Bukti Keterangan Saksi yang Memiliki Hubungan Darah dengan Terdakwa Dalam Tindak Pidana Pencurian Dalam Keluarga}

Pembuktian merupakan pengaturan yang dimana berisi tentang pedoman dan tata cara yang dibenarkan oleh undang-undang dalam hal membuktikan suatu kesalahan yang dijatuhkan kepada mereka yang dinyatakan bersalah. Pembuktian juga merupakan ketentuan yang mengatur mengenai alat-alat bukti sesuai dengan yang dinyatakan dalam undang-undang dan akan membantu hakim dalam proses persidangan.

Alat bukti merupakan suatu yang dapat berupa benda dan pernyataan secara lisan yang dapat dijadikan acuan dalam penjatuhan dakwaan terhadap terdakwa. Alat bukti yang digunakan adalah benda yang ditemukan di tempat kejadian atau kesaksian yang diberikan oleh saksi yang mendengar dan melihat terjadinya suatu tindak pidana. Bukti berupa keterangan yang disampaikan langsung oleh saksi adalah alat bukti yang paling utama di suatu tindak pidana. Hampir semua yang menjadi pembuktian dalam tindak pidana tidak luput dari keterangan saksi. Pembuktian alat bukti saksi dapat berupa, pemanggilan terhadap saksi, pengucapan sumpah oleh saksi, keterangan yang disampaikan saksi bersifat bebas tanpa adanya intervensi dari manapun,

Pemanggilan saksi dilakukan oleh penuntun umum, yang dalam surat pemanggilanya harus memuat tanggal, hari dan jam sidang serta atas perkara apa saksi dipanggil dan ketika saksi dipangil untuk dimintai keterangan selama persidangan. Saksi harus mengucap sumpah, wajib mengucapkan sumpah. Karena keterangan saksi yang diberikan setelah mengucap sumpah merupakan alat bukti yang sah. Jika keterangan tersebut diberikan tanpa mengucapkan sumpah sebelumnya maka keterangan tersebut dinyatakan tidak sah.

Keterangan yang diberikan saksi harus bersifat bebas, yang dimaksudkan keterangan bersifat bebas adalah keterangan yang diberikan tanpa adanya intervensi dari pihak manapun, jadi saksi selama menyampaikan kesaksiannya bisa secara lugas dan jelas tanpa menerima ancaman dan tekanan. Dari semua penjelasan diatas maka pembuktian dengan menggunakan alat bukti keterangan dari saksi yaitu saksi yang hadir dalam persidangan, mengucap janji dan sumpah sebelumya dan saksi memberikan keterangan dan kepastian bagi hakim sesuai dengan apa yang dilihat dan dialami sendiri oleh saksi.

Hambatan internal adalah hambatan yang terjadi didalam ruang lingkup persidangan, hambatan-hambatan yang dapat terjadi ialah keterangan saksi yang memiliki hubungan keluarga dengan terdakwa dari suatu tindak pidana pencurian apabila asas minimum pembuktian itu sendiri tidak terpenuhi. Asas minimum dalam pembuktian adalah harus terpenuhinya bukti kesalahan yang telah dilakukan oleh terdakwa. Prinsip yang mengatakan minimum dalam pembuktian dianggap cukup apabila: sudah menyertakan dua alat bukti, karena satu alat bukti tidak cukup. Pemeriksaan alatalat bukti dalam kasus pencurian yang dilakukan oleh keluarga, keterangan dari saksi yang memiliki hubungan darah tidak dapat dijadikan alat bukti yang sah, melainkan hanya dijadikan petunjuk atau penunjang alat bukti yang sah lainnya. Atas dasar itulah maka pentingnya alat bukti yang menunjang 
lainnya, sesuai dengan bunyi pasal 188 ayat (1) KUHAP) Pasal 189 ayat (1) KUHAP menyatakan bahwa keterangan yang diberikan oleh terdakwa dalam persidangan tentang perbuatan yang telah dilakukannya atau yang dialami dan dilakukan sendiri. Jika dijabarkan mengenai yang dimaksud dari keterangan terdakwa adalah, hal yang disampaikan langsung oleh terdakwa di pengadilan, hal yang dijelaskan oleh terdakwa sesuai dengan perbuatan yang telah dilakukannya,

Keterangan yang disampaikan di pengadilan berupa penjelasan yang dirasakan langsung oleh terdakwa maupun pernyataan secara langsung yang berupa jawaban atau penjelasan mengenai apa yang sudah dilakukan terdakwa dan semua hal tersebut dikemukakan di hadapan hakim dalam proses persidangan. Tentang perbuatan yang ia ketahui dan lakukan sendiri. Tentang apa yang dilakukan terdakwa adalah pernyataan atau pengakuan atas perbuatan yang telah dilakukannya yang dijadikan sebagai alat bukti. Tentang apa yang diketahui oleh terdakwa menurut undang-undang adalah pernyataan mengenai informasi atas suatu kejadian yang diketahui secara langsung oleh terdakwa. Dan apa yang dialami secara langsung oleh terdakwa

Keterangan terdakwa hanya dapat dijadikan sebagai alat bukti untuk dirinya sendiri, apa yang diterankan dan diungkapkan dalam suatu persidangan yang telah dinyatakan sebagai terdakwa, hanya dapat digunakan sebagai alat bukti untuk dirinya sendiri, pada saat terdakwa menyatakan dirinya tidak bersalah maka prinsip minimum dalam pembuktian yang mewajibkan harus ada dua bukti yang dikatakan sah yang dijadikan acuan dalam membuktikan kesalahan terdakwa tidak terenuhi. Sehingga terdakwa dapat dinyatakan tidak bersalah dan dapat dibebaskan.

Hambatan eksternal merupakan semua hal yang memiliki keterkaitan atau hubungan dengan persidangan, dimana proses pembuktian saksi yang bersangkutan didatangkan langsung dimuka pengadilan, hambatan dalam penghadiran saksi tersebut bisa saja terjadi. Hambatan dalam penghadiran saksi bisa terjadi karena saksi sakit atau menyatakan alasan yang jelas atas ketidakhadirannya. Saksi diperiksa secara tersendiri dan mereka wajib memberikan keterangan yang sebenarnya sesuai dengan apa yang mereka ketahui. tetapi apabila saksi tidak bisa hadir karena sakit atau alasan tertentu, maka hakim ketua mempunyai hak menyangka bahwa saksi memang tidak berkenan untuk hadir dan hakim bisa memerintahkan dengan paksa agar saksi tersebut dihadirkan.

\section{SIMPULAN DAN SARAN}

\section{Simpulan}

Dapat disimpulkan bahwa, kekuatan dari alat bukti saksi dalam status saksi memiliki hubungan darah dengan terdakwa, maka keterangan dari saksi sangat diperlukan dalam pebuktian di persidangan. Sebagai saksi A De Charge yang memiliki hubungan darah maka terdakwa juga memiliki hak sebagai saksi apabila saksi juga menghendaki hal tersebut dan penuntuk umum juga menyetujuinya, maka dapat memberikan keterangan apabila sudah disumpah sesuai dengan bunyi pasal 169 ayat (1) KUHAP, tetapi sebaliknya jika terdakwa dan penuntut umum tidak menyetujui, maka saksi tersebut masih dapat memberi keterangan tapi tanpa disumpah, saksi tersebut menjadi alat bukti yang tidak sah tapi juga dipertimbangkan oleh hakim dalam menjatuhkan putusan. Adapun hambatan yang ditemui saat proses pembuktian dengan melibatkan saksi yang memiliki keterkaitan atau hubungan darah dengan terdakwa itu sendiri, hambatan yang dapat terjadi adalah apabila asas minimum pembuktian terpenuhi. Asas minimum pembuktian merupakan prinsip yang didalamnya mengatur batasan-batasan yang harus dipenuhi dalam proses pembuktian atau membuktikan kesalahan atau tindak pidana yang telah dilakukan oleh terdakwa. Lebih jelasnya asas minimum pembuktian itu adalah suatu prinsip mengenai apa yang menjadi pedoman dalam menilai cukup atau tidaknya alat bukti dalam membuktikan kesalahan terdakwa.

\section{Saran}

Sebaiknya dalam pembuatan undang-undang harus lebih diperhatikan lagi mengenai pengaturanpengaturan di dalamnya agar pengaturan tersebut memiliki kekuatan dalam membuktikan keterangan yang diberikan saksi yang memiliki keterkaitan atau hubungan darah dengan terdakwa pidana pencurian dalam keluarga dan dalam persidangan harus mencari atau mendapatkan minimal dua alat bukti yang nantinya dinyatakan sah oleh ketentuan yang berlaku. Agar tidak menimbulkan perihal yang menghambat dalam proses pembuktian dengan menggunakan alat bukti dari keterangan yang disampaikan oleh saksi yang memiliki keterkaitan atau hubungan darah dengan terdakwa yang pencurian dalam suatu keluarga. 


\section{DAFTAR PUSTAKA}

Alfitra. (2018). Hukum Pembuktian Dalam Beracara Pidana, Perdata dan Korupsi di Indonesia. Raih Asa Sukses, Jakarta.

Harahap, M. Y. (2012). Pembahasan Permasalah dan Penerapan KUHP Pemeriksaan Sidang Pengadilan, Banding, Kasasi dan Peninjauan Kembali. Sinar Grafika, Jakarta.

Husin, K. (2016). Sistem Peradilan Pidana. Sinar Grafika, Jakarta.

Kamu, M. (2019). Kekuatan Alat Bukti Keterangan Saksi Yang Memiliki Hubungan Darah dengan Terdakwa Dalam Tindak Pidana Pencurian (Penerapan Pasal 367 Ayat (2) No. Pasal 362 KUHP). Lex Et Societatis, 7(1), 56-65.

Marzuki, P. M. (2008). Pengantar Ilmu Hukum. Kencana, Jakarta.

Nofandhi, A. (2018). Tinjauan Pertimbangan Hakim Terhadap Keterangan Saksi yang Memiliki Hubungan Darah dengan Terdakwa Dalam Tindak Pidana Pecurian Dalam Keluarga (Studi Putusan Nomor 187/Pid. B/2015/PN. Kln). Verstek: Jurnal Hukum Acara, 6(1), 11-18.

Pratiwi, T., \& P., N. W. (2016). Keabsahan Pemberian Kesaksian oleh Seseorang yang Mempunyai Hubungan Keluarga Sedarah dengan Terdakwa di Persidangan. Jurnal Verstek, 1(1), 194-202.

Remincel. (2019). Kedudukan Saksi Dalam Hukum Pidana. Ensiklopedia of Journal, 1(2), 268-273.

W, L. J. K. (2017). Kedudukan Saksi yang Mempunyai Hubungan Darah Dalam Perkara Tindak Pidana Penculikan Anak/Bayi (Studi Putusan Pengadilan Negeri Slawi Nomor: 46/Pid.Sus/2013/PN.Slw). Jurnal Verstek, 5(3), 237-246.

Waluyo, B. (1991). Penelitian Hukum Dalam Praktek. Sinar Grafika, Jakarta. 